\title{
Effects of the Incorporation of
} Dracaena arborea Roots Powder on Growth Performance and Some Haematological Parameters in Guinea Pigs (Cavia porcellus)

\author{
Bertine Marie Noël Noumbissi ${ }^{*}$, Bello Maliki Ibrahim² ${ }^{2}$ Margaret Mary Momo Chongsi ${ }^{1}$, \\ Souley Bagari Iya², Clémence-Aggy Njehoya², Emile Miégoué1, Fernand Tendonkeng1 \\ ${ }^{1}$ Department of Zootechnic, Faculty of Agronomy and Agricultural Sciences, University of Dschang, Dschang, Cameroon \\ ${ }^{2}$ Institut de Recherche Agricole pour le Développement, Centre de Recherche Agricole de Wakwa, Ngaoundéré, Cameroun \\ Email: ^dadamanol@yahoo.fr, noumbimanol@yahoo.fr, ibramaliki92@gmail.com, magaretchongsi@yahoo.fr, \\ iyasouley@yahoo.fr, aggyclem@yahoo.fr, migoumile@yahoo.fr, ftendonkeng@gmal.com
}

How to cite this paper: Noumbissi, B.M.N., Ibrahim, B.M., Chongsi, M.M.M., Iya, S.B., Njehoya, C.-A., Miégoué, E. and Tendonkeng, F. (2021) Effects of the Incorporation of Dracaena arborea Roots Powder on Growth Performance and Some Haematological Parameters in Guinea Pigs (Cavia porcellus). Open Journal of Animal Sciences, 11, 458-472.

https://doi.org/10.4236/ojas.2021.113032

Received: May 8, 2021

Accepted: July 11, 2021

Published: July 14, 2021

Copyright $\odot 2021$ by author(s) and Scientific Research Publishing Inc. This work is licensed under the Creative Commons Attribution-NonCommercial International License (CC BY-NC 4.0). http://creativecommons.org/licenses/by-nc/4.0/ (c) (i) (3) Open Access

\begin{abstract}
The present study was assigned to evaluate the Effect of Dracaena arborea roots powder in ration on growth performances and some hematological parameters in the guinea pig on diet supplemented with graded levels of incorporation. A total of 40 guinea pigs weaned of local breed and aged 3 weeks were divided into 4 identical batches. Each of the groups was randomly assigned one of 4 rations containing different levels of the powder from Dracaena arborea $(\mathrm{Da})$ roots: $\mathrm{Da} 0 ; \mathrm{Da} 0.25 ; \mathrm{Da} 0.5$ and $\mathrm{Da} 0.75$. The results at the 11 th week of breeding showed that the highest intake $(21.13 \mathrm{~g} / \mathrm{d})$ was obtained with the Da0.5 ration. The highest live weight $(372.50 \mathrm{~g})$ and total weight gains were obtained with the Da0.25 ration. In addition, the highest commercial $(161.75 \mathrm{~g})$ and conventional $(307.75 \mathrm{~g})$ carcass weights and large intestine length $(99.5 \mathrm{~cm})$ were obtained with the D0.25 ration. The highest values for granulocytes $\left(0.250 .10^{3} / \mu \mathrm{l}\right)$, platelets $\left(805.10^{3} / \mu \mathrm{l}\right)$ and lymphocytes $\left(6.92 .10^{3} / \mu \mathrm{l}\right)$ were respectively, obtained with the rations containing $\mathrm{Da}$; D0.5 and D0.75. In view of the above, Dracaena arborea roots powder can be used at a rate of $0.25 \%$ in the ration, to improve the productivity of the guinea pig (Cavia porcellus).
\end{abstract}

\section{Keywords}

Cavia porcellus, Dracaena arborea, Growth Performance, Haematological Parameters 


\section{Introduction}

The demographic growth of the populations of the Third World countries induces a strong demand for proteins of animal origin. To solve this problem, particular emphasis must be placed on mini-breeding in general and the breeding of guinea pigs (Caviaculture) in particular, which could be an alternative to fighting against malnutrition and poverty in Africa in general and in Cameroon in particular [1]. In fact, guinea pig is monogastric with a strictly herbivorous diet, which makes better use of local food resources [2]. It is mostly bred and consumed in western and southern Cameroon. It is involved in various cultural events such as dowries, weddings and funerals. In addition, its breeding can help increase the income of the peasant and it is also used in science as an experimental animal [3].

Despite these nutritional, economic and cultural advantages, caviaculture is still slow to take off because of its low productivity due to the instability of its intestinal flora [4] [5]. Indeed, a variation of its diet would be likely to unbalance its intestinal microflora leading to poor growth and a high rate of mortality. Concerned with this problem, several studies have been carried out with the aim of discovering substances capable of stabilizing the intestinal flora, preventing mortalities on one hand and improving the growth of animals on the other hand. As such, feed additives in general and phytobiotics in particular have seen their use increase in recent years [6]. Indeed, phytobiotics are preparations made using the roots, barks, leaves, stems, plant extracts, spices and/or essential oils which, in animal feed, could improve the zootechnical performance of animals.

Dracaena arborea is a plant of the Asparagaceae family [7], native to Central Africa, used in traditional pharmacopoeia to treat epilepsy and infertility among others [8]. Indeed, this plant reveals the presence of bioactive compounds such as saponins and terpenoids which, according to Abdel-Ghaney et al. [9] and Chakraborty et al. [10] are growth promoters and are believed to have a beneficial effect on the intestinal microflora by increasing the absorption of nutrients. The aim of the present study is therefore to contribute to the improvement of the diet of guinea pigs, through the valuation of Dracaena arborea roots powder as a feed additive, on growth characteristics and some hematological parameters of young guinea pigs post-weaned.

\section{Materials and Methods}

\subsection{Study Zone}

The study was carried out from January to April 2020 at the Application and Research Farm (FAR) and the Animal Production and Nutrition Research Unit (URPRONAN) of the University of Dschang. Dschang is a locality located in the West Region of Cameroon, at $1400 \mathrm{~m}$ altitude and $05^{\circ} 26^{\prime}$ North latitude and $10^{\circ} 26^{\prime}$ East longitude. The average temperature in the area is $20^{\circ} \mathrm{C}$ and the relative humidity reaches $83.5 \%$. The rainfall, which is between 1500 and $2000 \mathrm{~mm}$, is unevenly distributed between a rainy season (from mid-March to mid-November) 
and a dry season (from mid-November to mid-March).

\subsection{Animal Equipment and Housing}

The study involved 40 weaned, local breed, 3-week-old guinea pigs (20 males and 20 females) from the FAR of the University of Dschang. The animals were randomly distributed into 4 groups or treatments of 10 subjects each $(05$ males and 05 females) and kept in boxes $(1.25 \mathrm{~m}$ in length, $0.60 \mathrm{~m}$ in width and $0.25 \mathrm{~m}$ in height) constructed with plywood and fitted with wire mesh covers to protect animals from predators.

\subsection{Plant Material}

The plant material consisted of fresh young roots of Dracaena arborea and Trypsacum laxum. The young roots, harvested at the foot of an adult Dragon tree in Dschang were then chopped to a size of about $5 \mathrm{~cm}$, dried in an oven set at $40^{\circ} \mathrm{C}$ for 48 hours, crushed and sieved using a $0.9 \mathrm{~mm}$ diameter sieve. The powder thus obtained was analyzed at URPRONAN to determine its chemical composition. Trypsacum laxum, used as a staple food, was harvested daily at the FAR and pre-wilted before being fed ad libitum to the animals the next day. The chemical compositions of Dracaena arborea and Trypsacum laxum powder are shown in Table 1.

\subsection{Formulation of the Different Experimental Rations}

Four rations were made from the different levels of incorporation of Dracena arborea roots powder into the concentrated feed (Table 2) consisting of ingredients purchased from local agricultural by-product dealers. As such, the rations $\mathrm{Da} 0 ; \mathrm{Da} 0.25 ; \mathrm{Da} 0.5$ and $\mathrm{Da} 0.75$ were formulated from the respective incorporation, of $0 \% ; 0.25 \%$; $0.5 \%$ and $0.75 \%$ Dracena arborea. Each group or batch of animals received, in addition to Trypsacum laxum served ad libitum, $40 \mathrm{~g}$ of the considered ration as follows:

- Control or basic ration Da0: Trypsacum laxum ad libitum $+40 \mathrm{~g}$ of feed composed of $0 \%$ Dracena arborea powder/animal/day (Batch D0);

Table 1. Bromatological composition of Dracaena arborea roots powder.

\begin{tabular}{ccc}
\hline \multirow{2}{*}{ Chemical composition } & \multicolumn{3}{c}{ Quantities } \\
\cline { 2 - 3 } & 91.61 & Trypsacum laxum \\
\hline Dry matter (\%) & 93.78 & 94.28 \\
Organic matter (\%) & 10.42 & 84.63 \\
Crude protein (\%) & 6.60 & 13.26 \\
Fats (\%) & 26.20 & $/$ \\
Crude cellulose (\%) & 6.23 & 37.77 \\
Ash (\%) & 1731.97 & 08.17 \\
\hline
\end{tabular}


Table 2. Percentage composition and bromatological characteristics of the compound feed.

\begin{tabular}{cc}
\hline Ingredients & Proportion of ingredients (\%) \\
Maize & 34 \\
Wheat middlings & 30 \\
Groundnut meal & 14 \\
Kernel meal & 15 \\
Fish meal & 2 \\
Shell & 2 \\
$\star$ Premix $2 \%$ & 2 \\
Palm oil (Litre) & 1 \\
Total & 100 \\
\hline Crude protein (\%) & \\
Crude cellulose (\%) & 17.71 \\
Digestible energy (Kcal/Kg) & 7.97 \\
Ash (\%) & 2841.91 \\
Fats (\%) & 15.88 \\
\hline
\end{tabular}

${ }^{*}$ Premix 2\%: Crudeprotein: 40\%; Lysine: 3.3\%; Methionine: 2.4\%; Calcium: 8\%; Phosphorus: 2.05\%; Metabolizableenergy: $2078 \mathrm{kcal} / \mathrm{kg}$.

- Ration Da0.25: Trypsacum laxum ad libitum + $40 \mathrm{~g}$ of feed composed of 0.25\% Dracena arborea powder/animal/day (Batch Da0.25);

- Ration Da0.5: Trypsacum laxum ad libitum + $40 \mathrm{~g}$ of feed composed of 0.5\% Dracena arborea powder/animal/day (Batch $\mathrm{Da} 0.5$ );

- Ration Da0.75: Trypsacum laxum ad libitum $+40 \mathrm{~g}$ of feed composed of 0.75\% Dracena arborea powder/animal/day (Batch Da0.75).

\subsection{Experimental Design}

Forty (40) weaned guinea pigs (20 males and 20 females), of local breeds aged between 3 to 4 weeks were randomly assigned to 4 groups or batches of 10 subjects each. Each batch consisted of 05 males and 05 females housed separately to avoid mating. Feed rations were randomly assigned to different groups of animals. The control or basic ration allocated to group D0 did not contain Dracaena arborea powder. The animals of batches D2, D3 and D4 received in addition to the basic ration, $0.25 \%$ (ration $\mathrm{Da} 0.25$ ); $0.5 \%$ (Da0.5 ration) and $0.75 \%$ (Da0.75 ration) respectively, of Dracaena arborea roots powder incorporated in the compound feed. Drinking water containing vitamin C (185 mg in 31 of drinking water) was served ad libitum.

\subsection{Growth Performance Assessment}

The animals were fed once a day, between 7 am and $9 \mathrm{am}$, with their respective rations. At the start of the test, then every week (every 07 days), the animals were 
weighed and the weights recorded for the evaluation of the weight change from the $3 \mathrm{rd}$ to the $11^{\text {th }}$ week of age as well as the total weight gains (TG) and average daily gains (ADG).

\subsection{Evaluation of Carcass Characteristics and Some Digestive Organs}

At 11 weeks of age, animals from each batch were subjected to a 12 hour fasting period, then slaughtered by cervical dislocation and throat bled to assess carcass characteristics, weights and measurements of the organs involved in digestion. The carcass yields, lengths and proportions of the different organs (digestive tract, intestine and cecum) in relation to the live weight of the animals at slaughter were evaluated. All the weights were measured using a digital balance with a capacity of $7 \mathrm{~kg}$ and a precision of $1 \mathrm{~g}$. The length of the bowel was taken with a precision $1 \mathrm{~mm}$ tape measure.

\subsection{Evaluation of Haematological Parameters}

When the animals were slaughtered as described above, their blood was collected directly from the jugular vein using heparinized tubes (with anticoagulant), for the determination of the concentration of red and white blood cells, lymphocytes, monocytes, granulocytes, blood platelets, hemoglobin, and determination of hematocrit, mean blood cell volume, and mean hemoglobin concentration. All these hematological analyses were performed using the Genius electronic hemacytometer (Model KT-6180, S/N 701106101557).

\subsection{Statistical Analyses}

The data collected was subjected to one-way analysis of variance (ANOVA) (feed ration) according to the general linear model (MLG). When there were significant differences between treatments, means were separated using the Waller Duncan test at 5\% significance level [11]. The analysis software used was SPSS 20.0

\section{Results}

\subsection{Effects of Incorporating Dracaena arborea Root Powder on Feed Intake in Guinea Pigs}

Figure 1 illustrates the dietary intake of young guinea pigs at week 11, depending on the treatments and it appears that the values were not significantly ( $p>$ $0.05)$ different between the rations.

\subsection{Effects of the Incorporation of Dracaena arborea Root Powder on the Weekly Weight Development of Guinea Pigs from the $3^{\text {rd }}$ to the $11^{\text {th }}$ Week of Age}

The weekly weight evolution of guinea pigs from the $3^{\text {rd }}$ to the $11^{\text {th }}$ week of age is illustrated in Figure 2. It appears that the addition of Dracaena arborea roots powder to the ration resulted in an increase in live weight of weaned animals 


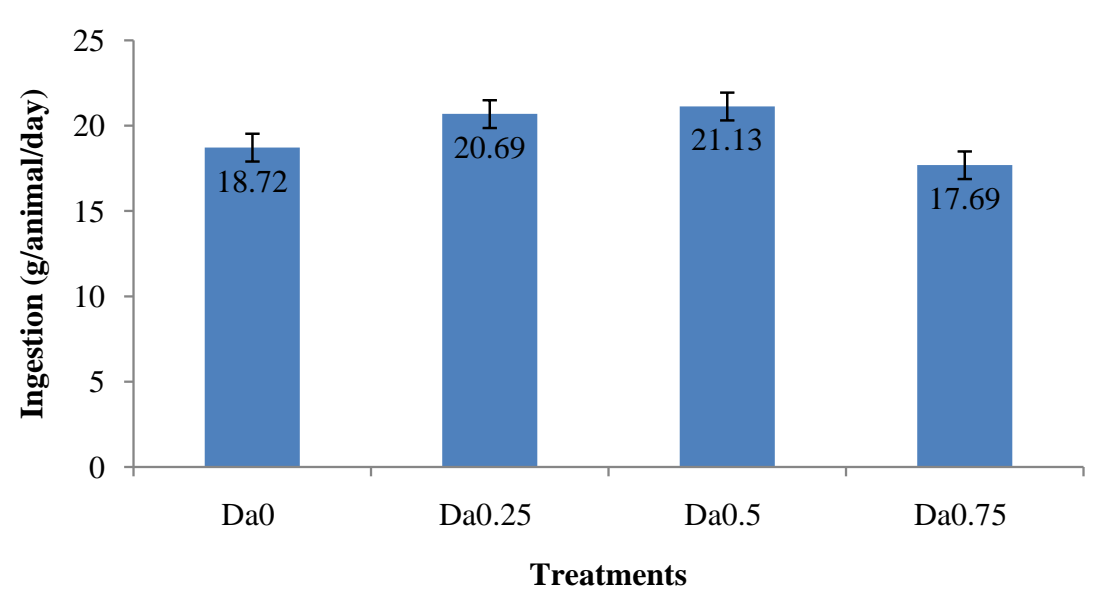

Figure 1. Ingestion of guinea pigs according to treatment, at week $11 . \mathrm{Da} 0=$ Control; Da0.25 $=$ Control $+0.25 \%$ of Dracaena arborea; Da $0.5=$ Control $+0.5 \%$ of Dracaena arborea; $\mathrm{Da} 0.75=$ Control $+0.75 \%$ of Dracaena arborea.

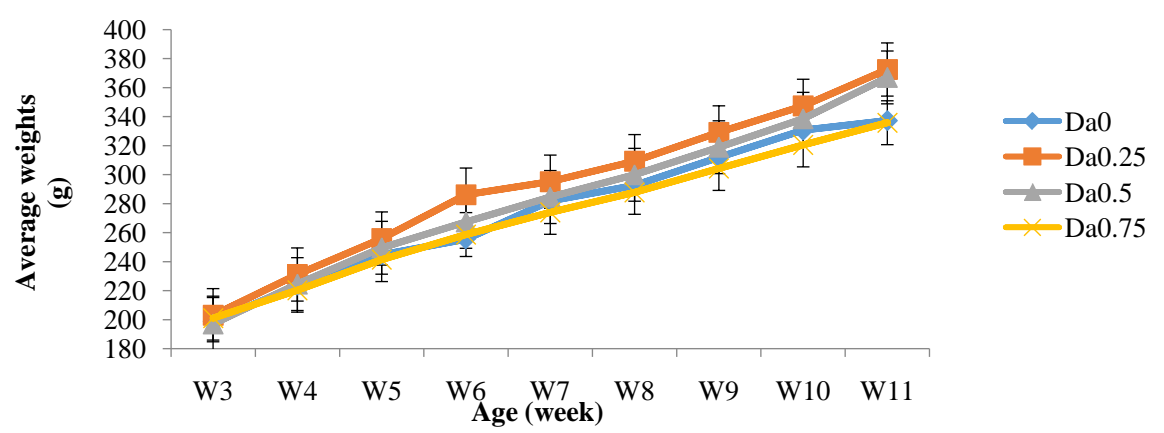

Figure 2. Weekly weight evolution of young guinea pigs according to the treatments, from the $3^{\text {rd }}$ to the $11^{\text {th }}$ week of age. $\mathrm{Da} 0=$ Control; Da0.25 $=$ Control $+0.25 \%$ of Dracaena arborea; Da0.5 $=$ Control $+0.5 \%$ of Dracaena arborea, Da0.75 $=$ Control $+0.75 \%$ of Dracaena arborea; W: Week.

from the $3^{\text {rd }}$ to the $11^{\text {th }}$ week of age, regardless of the ration. However, the highest live weight was obtained with the Da0.25 ration which, moreover, was comparable ( $p>0.05$ ) to that of weaned animals consuming the Da0.5 ration and significantly higher $(\mathrm{p}<0.05)$ than those obtained with the $\mathrm{Da} 0$ and $\mathrm{Da} 0.75$ rations, which remained comparable $(p>0.05)$ with each other.

\subsection{Effects of Incorporating Dracaena arborea Root Powder on Total Weight Gain (TG)}

The comparison of the total weight gains of guinea pigs at the $11^{\text {th }}$ week of age, depending on the rations, is shown in Figure 3.

It emerges from this Figure that the total gains recorded were $139.25 \mathrm{~g}, 170.6$ g, $161.75 \mathrm{~g}$ and $134.50 \mathrm{~g}$ respectively for the Da0, Da0.25, Da0.5 and Da0.75 treatments. These values for the animals which received the Da0.25 and $\mathrm{Da} 0.5$ rations were comparable $(\mathrm{p}>0.05)$ to each other and significantly higher $(\mathrm{p}<$ 0.05) than those of the animals which received the $\mathrm{Da} 0$ and $\mathrm{Da} 0.75$ rations which, moreover, were comparable $(\mathrm{p}>0.05)$. 


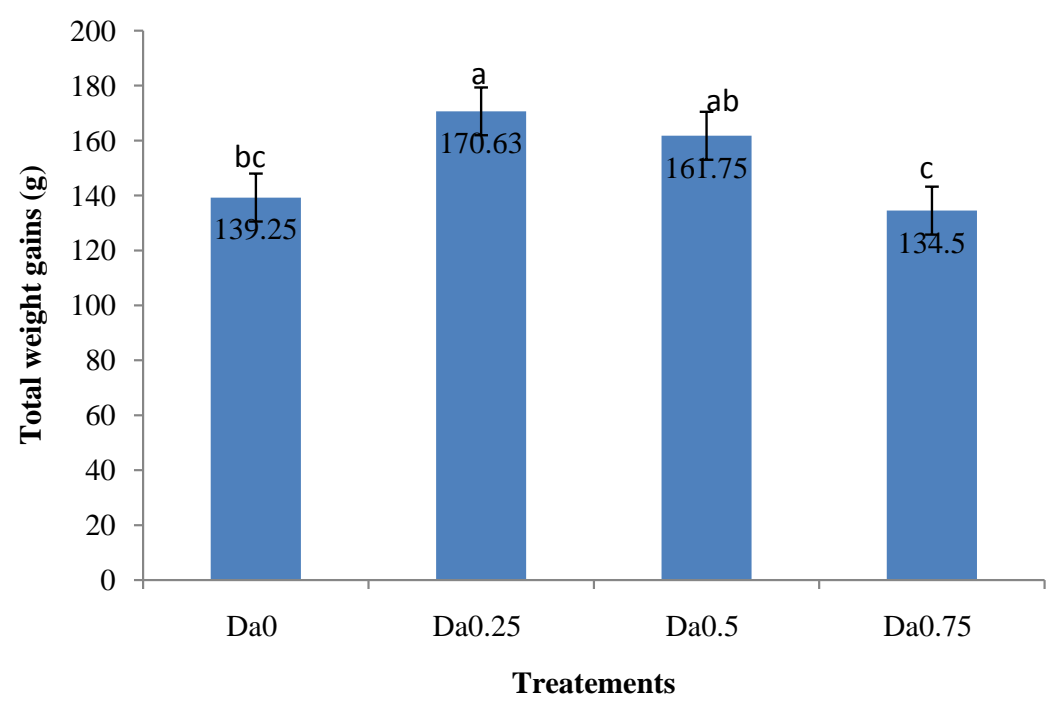

Figure 3. Comparison of total weight gains for different treatments, at Week 11. a, b, c: the means with the same superscripts on the same row are not significantly different $(\mathrm{p}>$ 0.05); Da0: Control; Da0.25 = Control $+0.25 \%$ of Dracaena arborea; Da0.5 = Control + $0.5 \%$ of Dracaena arborea; $\mathrm{Da} 0.75=$ Control $+0.75 \%$ of Dracaena arborea.

\subsection{Effects of Incorporating Dracaena arborea Root Powder on Average Daily Weight Gain (ADG)}

The comparison, according to the rations, of the average daily gains at the $11^{\text {th }}$ week is illustrated by Figure 4 and there we observe that the highest ADG (3.04 g) was observed with the ration $\mathrm{Da} 0.25$ which, nevertheless, was statistically comparable ( $\mathrm{p}>0.05)$ to that of the animals of the Da0.5 batch $(2.88 \mathrm{~g})$, moreover comparable to that of the animals of the $\mathrm{Da} 0$ batch $(2.48 \mathrm{~g})$ and significantly $(\mathrm{p}<0.05)$ greater than that of the animals of batch $\mathrm{Da} 0.75(2.4 \mathrm{~g})$.

\subsection{Effects of Incorporating Dracaena arborea Root Powder on the Consumption Index}

It appears from Figure 5 that the consumption indices of the different rations were not significant $(\mathrm{p}>0.05)$ influenced by the addition of powder from the roots of Dracaena arborea in the ration.

\subsection{Effects of the Incorporation of Dracaena arborea Roots Powder on Carcass Characteristics and Some Organs of the Digestive Tract of the Guinea Pig}

Table 3 shows the effects of incorporating Dracaena arborea roots powder on the carcass characteristics of guinea pigs at the $11^{\text {th }}$ week of age. It appears that the live weight at slaughter and the weight after bleeding recorded with the animals receiving the $\mathrm{Da} 0.25$ and $\mathrm{Da} 0.5$ rations were comparable $(\mathrm{p}>0.05)$ but significantly higher $(\mathrm{p}<0.05)$ than those of animals given the $\mathrm{Da} 0$ and $\mathrm{Da} 0.75$ rations which, moreover, were comparable $(p>0.05)$ to each other. The same trend was observed with commercial and conventional carcass weights. The addition of powder from the roots of Dracaena arborea had no significant effect 


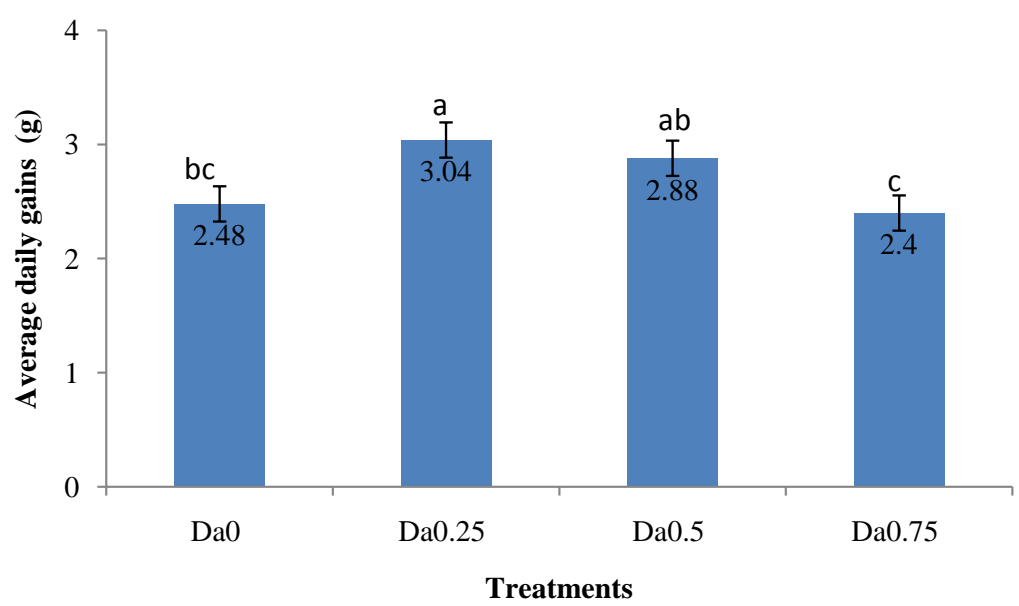

Figure 4. Comparison of average daily weight gains according to the different treatments, at the 11th week. a, b, c: the means with the same superscripts on the same row are not significantly different $(\mathrm{p}>0.05) ; \mathrm{Da} 0=$ Control; $\mathrm{Da} 0.25=$ Control $+0.25 \%$ of Dracaena arborea; $\mathrm{Da} 0.5=$ Control $+0.5 \%$ of Dracaena arborea Da $0.75=$ Control $+0.75 \%$ of Dracaena arborea.

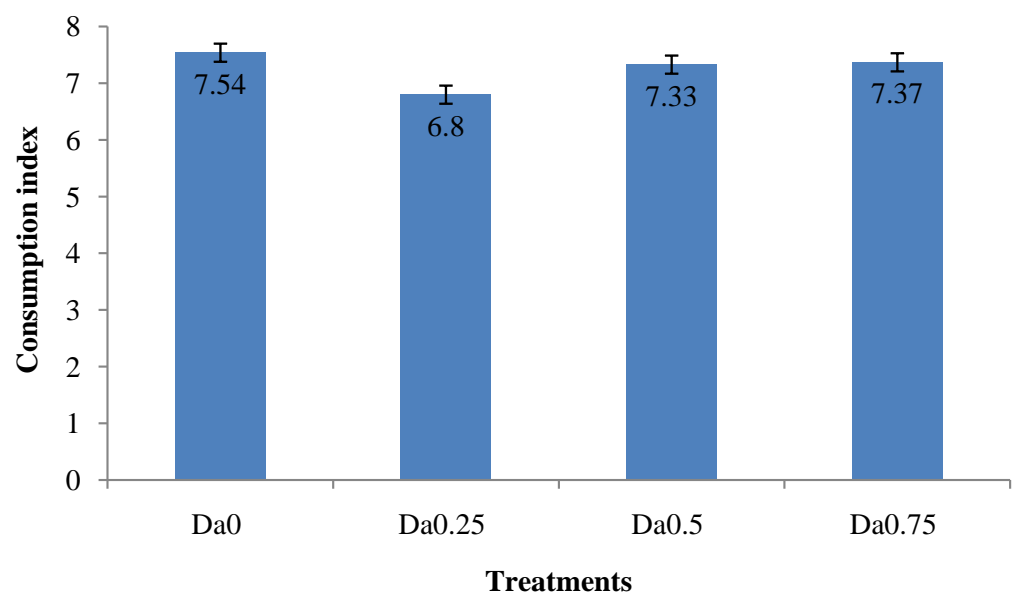

Figure 5. Comparison of the consumption index between the different treatments, at the $11^{\text {th }}$ week. $\mathrm{Da} 0=$ Control; Da0.25 $=$ Control $+0.25 \%$ of Dracaena arborea Da0.5 $=$ Control $+0.5 \%$ of Dracaena arborea; $\mathrm{Da} 0.75=$ Control $+0.75 \%$ of Dracaena arborea .

Table 3. Characteristics of the guinea pig carcass, according to the treatments.

\begin{tabular}{|c|c|c|c|c|c|c|}
\hline \multirow{2}{*}{ Characteristics } & \multicolumn{4}{|c|}{ Treatments } & \multirow{2}{*}{ MSD } & \multirow{2}{*}{$\mathrm{p}$} \\
\hline & $\mathrm{Da} 0$ & $\mathrm{Da} 0.25$ & $\mathrm{Da} 0.5$ & $\mathrm{Da} 0.75$ & & \\
\hline \multicolumn{7}{|c|}{ Weights (g) } \\
\hline Live weight at slaughter & $337.25^{\mathrm{b}}$ & $372.50^{\mathrm{a}}$ & $367.00^{\mathrm{a}}$ & $335.75^{\mathrm{b}}$ & 13.26 & 0.041 \\
\hline Weight after bleeding & $325.75^{\mathrm{b}}$ & $364.50^{\mathrm{a}}$ & $353.75^{\mathrm{a}}$ & $320.50^{\mathrm{b}}$ & 13.138 & 0.031 \\
\hline Head & $42.5^{\mathrm{a}}$ & $49.00^{\mathrm{a}}$ & $49.5^{\mathrm{a}}$ & $45.00^{\mathrm{a}}$ & 3.046 & 0.160 \\
\hline Heart & $1.25^{\mathrm{a}}$ & $1.5^{\mathrm{a}}$ & $1.37^{\mathrm{a}}$ & $1.01^{\mathrm{a}}$ & 0.312 & 0.063 \\
\hline Kidneys & $3.42^{\mathrm{a}}$ & $3.51^{\mathrm{a}}$ & $3.26^{\mathrm{a}}$ & $3.75^{\mathrm{a}}$ & 0.192 & 0.552 \\
\hline Digestive tube & $69.75^{\mathrm{a}}$ & $75.5^{\mathrm{a}}$ & $70.75^{\mathrm{a}}$ & $71^{\mathrm{a}}$ & 2.739 & 0.627 \\
\hline
\end{tabular}


Continued

\begin{tabular}{|c|c|c|c|c|c|c|}
\hline Commercial carcass & $119.25^{\mathrm{b}}$ & $161.75^{\mathrm{a}}$ & $131.75^{\mathrm{ab}}$ & $127.75^{\mathrm{b}}$ & 3.705 & 0.049 \\
\hline Classical carcass & $248.25^{\mathrm{b}}$ & $307.75^{\mathrm{a}}$ & $271.75^{\mathrm{ab}}$ & $236.75^{\mathrm{b}}$ & 2.342 & 0.026 \\
\hline \multicolumn{7}{|c|}{ Yields (\%) } \\
\hline Commercial carcass & $32^{\mathrm{a}}$ & $39.5^{\mathrm{a}}$ & $34^{\mathrm{a}}$ & $33.25^{\mathrm{a}}$ & 0.227 & 0.482 \\
\hline Classical carcass & $64.5^{\mathrm{a}}$ & $75.75^{\mathrm{a}}$ & $69.5^{\mathrm{a}}$ & $64.25^{\mathrm{a}}$ & 0.849 & 0.603 \\
\hline \multicolumn{7}{|c|}{ Proportions of organs (\%) } \\
\hline Head/LWs & $11.026^{\mathrm{a}}$ & $12.079^{\mathrm{a}}$ & $12.699^{\mathrm{a}}$ & $12.382^{\mathrm{a}}$ & 1.265 & 0.818 \\
\hline Liver/LWs & $2.583^{\mathrm{a}}$ & $2.201^{\mathrm{a}}$ & $2.420^{\mathrm{a}}$ & $2.531^{\mathrm{a}}$ & 0.247 & 0.768 \\
\hline Kidneys/LWs & $0.757^{\mathrm{a}}$ & $0.646^{\mathrm{a}}$ & $0.736^{\mathrm{a}}$ & $0.764^{\mathrm{a}}$ & 0.068 & 0.661 \\
\hline Digestive tube/LWs & $17.847^{\mathrm{a}}$ & $18.447^{\mathrm{a}}$ & $17.992^{\mathrm{a}}$ & $19.342^{\mathrm{a}}$ & 0.845 & 0.727 \\
\hline
\end{tabular}

a, b: the means with the same superscripts on the same line are not significantly different ( $\mathrm{p}>0.05)$; MSD: Mean standard deviation; P: Probability (5\%); Da0 = Control; Da0.25 = Control $+0.25 \%$ of Dracaena arborea; $\mathrm{Da} 0.5=$ Control $+0.5 \%$ of Dracaena arborea; Da0.75 $=$ Control $+0.75 \%$ of Dracaena arborea; LWs: Live weight at slaughter.

( $p>0.05)$ on head, heart, kidney and entire digestive tract weights, as well as on commercial and classical carcass yields and organ proportions.

\subsection{Effects of the Incorporation of Dracaena arborea Roots Powder on the Characteristics of Some Organs of the Digestive Tract}

The weights and lengths of some digestive organs in guinea pigs at the $11^{\text {th }}$ week according to treatments are presented in Table 4 and it appears that apart from the weight of the empty caecum and the length of the large intestine which were significantly influenced $(\mathrm{p}<0.05)$, the addition of powder from the roots of Dracaena arborea had no significant effect ( $p>0.05)$ on the organs of the digestive tract, regardless of the ration.

\subsection{Effects of the Incorporation of Dracaena arborea Roots Powder on Some Haematological Parameters}

Table 5 shows the effect of powder from the roots of Dracaena arborea on some haematological parameters in guinea pigs at week 11. It emerges that the blood platelet levels of the animals consuming the $\mathrm{Da} 0$ and Da0.5 rations were comparable $(\mathrm{p}>0.05)$ and significantly higher $(\mathrm{p}<0.05)$ than those of the animals from the $\mathrm{Da} 0.25$ and $\mathrm{Da} 0.75$ batches which, moreover, were comparable ( $\mathrm{p}>$ $0.05)$ to each other. As regards lymphocytes (LYMPH), their concentrations in the animals of the $\mathrm{Da} 0.5$ and $\mathrm{Da} 0.75$ batches were comparable $(\mathrm{p}>0.05)$ to each other but significantly higher $(\mathrm{p}<0.05)$ than those animals from batches Da0 and $\mathrm{Da} 0.25$, which are otherwise comparable. The granulocyte concentration of the animals of the $\mathrm{Da} 0$ batch was significantly $(\mathrm{p}<0.05)$ higher than that of the animals of batches $\mathrm{Da} 0.25, \mathrm{Da} 0.5$ and $\mathrm{Da} 0.75$ which, moreover, were comparable ( $p>0.05)$ among themselves. Adding powder from the roots of Dracaena arborea to the ration had no significant effect $(\mathrm{p}>0.05)$ on the other parameters. 
Table 4. Weights and lengths of some organs of the digestive tract of guinea pigs, according to the treatments.

\begin{tabular}{|c|c|c|c|c|c|c|}
\hline \multirow{2}{*}{ Parameters } & \multicolumn{4}{|c|}{ Treatments } & \multirow{2}{*}{ MSD } & \multirow{2}{*}{$\mathrm{p}$} \\
\hline & $\mathrm{Da} 0$ & $\mathrm{Da} 0.25$ & $\mathrm{Da} 0.5$ & $\mathrm{Da} 0.75$ & & \\
\hline \multicolumn{7}{|c|}{ Weights (g) } \\
\hline Empty small intestine & $6.01^{\mathrm{a}}$ & $7.5^{\mathrm{a}}$ & $8.25^{\mathrm{a}}$ & $8.29^{\mathrm{a}}$ & 0.584 & 0.789 \\
\hline Empty large intestine & $6^{\mathrm{a}}$ & $6.5^{\mathrm{a}}$ & $7.75^{\mathrm{a}}$ & $7^{\mathrm{a}}$ & 0.729 & 0.377 \\
\hline Empty caecum & $6^{\mathrm{a}}$ & $6.75^{\mathrm{a}}$ & $5.75^{\mathrm{b}}$ & $5.25^{\mathrm{b}}$ & 0.451 & 0.020 \\
\hline \multicolumn{7}{|c|}{ Length $(\mathrm{cm})$} \\
\hline Small intestine & $139^{\mathrm{a}}$ & $141.75^{\mathrm{a}}$ & $141^{\mathrm{a}}$ & $136.75^{\mathrm{a}}$ & 3.702 & 0.788 \\
\hline Large intestine & $89.75^{\mathrm{ab}}$ & $99.5^{\mathrm{a}}$ & $95.5^{\mathrm{ab}}$ & $86.25^{\mathrm{b}}$ & 3.188 & 0.047 \\
\hline Caecum & $10.25^{\mathrm{a}}$ & $11.5^{\mathrm{a}}$ & $11.5^{\mathrm{a}}$ & $12.25^{\mathrm{a}}$ & 0.681 & 0.352 \\
\hline \multicolumn{7}{|c|}{ Density $(\mathrm{g} / \mathrm{cm})$} \\
\hline Caecum & $0.66^{\mathrm{a}}$ & $0.8^{\mathrm{a}}$ & $0.73^{\mathrm{a}}$ & $0.63^{\mathrm{a}}$ & 0.059 & 0.217 \\
\hline Intestine & $0.08^{\mathrm{a}}$ & $0.06^{\mathrm{a}}$ & $0.06^{\mathrm{a}}$ & $0.06^{\mathrm{a}}$ & 0.006 & 0.375 \\
\hline
\end{tabular}

a, b: the means with the same superscripts on the same line are not significantly different ( $\mathrm{p}>0.05)$; MSD: Mean Standard Deviation; P: Probability; $\mathrm{Da} 0=$ Control; Da0.25 $=$ Control $+0.25 \%$ of Dracaena arborea; $\mathrm{Da} 0.5=$ Control $+0.5 \%$ of Dracaena arborea $; \mathrm{Da} 0.75=$ Control $+0.75 \%$ of Dracaena arborea

Table 5. Effects of the incorporation of Dracaena arborea roots powder on some haematological parameters in guinea pigs.

\begin{tabular}{|c|c|c|c|c|c|c|}
\hline \multirow{2}{*}{ Parameters } & \multicolumn{4}{|c|}{ Treatments } & \multirow{2}{*}{ MSD } & \multirow{2}{*}{$\mathrm{p}$} \\
\hline & $\mathrm{Da} 0$ & $\mathrm{Da} 0.25$ & $\mathrm{Da} 0.5$ & $\mathrm{Da} 0.75$ & & \\
\hline $\operatorname{WBC}\left(10^{3} / \mu \mathrm{l}\right)$ & $5.55^{\mathrm{a}}$ & $5.54^{\mathrm{a}}$ & $5.275^{\mathrm{a}}$ & $5.1^{\mathrm{a}}$ & 1.276 & 0.177 \\
\hline $\operatorname{RBC}\left(10^{3} / \mu \mathrm{l}\right)$ & $5.8225^{\mathrm{a}}$ & $5.3275^{\mathrm{a}}$ & $5.905^{\mathrm{a}}$ & $5.8175^{\mathrm{a}}$ & 0.236 & 0.362 \\
\hline $\operatorname{PLT}\left(10^{3} / \mu \mathrm{l}\right)$ & $805^{\mathrm{a}}$ & $525.75^{\mathrm{b}}$ & $714.75^{\mathrm{a}}$ & $543.75^{\mathrm{b}}$ & 47.619 & 0.008 \\
\hline MHC (pg) & $24.9^{\mathrm{a}}$ & $25.625^{\mathrm{a}}$ & $25.4^{\mathrm{a}}$ & $25.3^{\mathrm{a}}$ & 0.285 & 0.524 \\
\hline LYMPH $\left(10^{3} / \mu \mathrm{l}\right)$ & $4.9^{\mathrm{b}}$ & $4.775^{\mathrm{b}}$ & $6.425^{\mathrm{a}}$ & $6.925^{\mathrm{a}}$ & 1.258 & 0.047 \\
\hline GRAN $\left(10^{3} / \mu \mathrm{l}\right)$ & $0.250^{\mathrm{a}}$ & $0.05^{\mathrm{b}}$ & $0.075^{\mathrm{b}}$ & $0.125^{b}$ & 0.057 & 0.039 \\
\hline HCT (\%) & $45.125^{\mathrm{a}}$ & $42.875^{\mathrm{a}}$ & $46.775^{\mathrm{a}}$ & $45.675^{\mathrm{a}}$ & 1.624 & 0.469 \\
\hline HGB (g/dl) & $14.15^{\mathrm{a}}$ & $13.675^{\mathrm{a}}$ & $15^{\mathrm{a}}$ & $14.75^{\mathrm{a}}$ & 0.559 & 0.423 \\
\hline MONO $\left(10^{3} / \mu \mathrm{l}\right)$ & $31.45^{\mathrm{a}}$ & $31.85^{\mathrm{a}}$ & $31.75^{\mathrm{a}}$ & $31.9^{\mathrm{a}}$ & 0.211 & 0.485 \\
\hline MGV (fL) & $78.95^{\mathrm{a}}$ & $80.6^{\mathrm{a}}$ & $80.15^{\mathrm{a}}$ & $79.45^{\mathrm{a}}$ & 0.565 & 0.439 \\
\hline
\end{tabular}

a, b: the means with the same letters on the same line are not significantly different ( $\mathrm{p}>0.05)$; MSD: Mean Standard Deviation; P: Probability; Da0 = Control; Da0.25 = Control + 0.25\% of Dracaena arborea; Da0.5 = Control $+0.5 \%$ of Dracaena arborea Da $0.75=$ Control $+0.75 \%$ of Dracaena arborea; $\mathrm{WBC}=$ white blood cells, $\mathrm{LYMPH}=$ lymphocytes, $\mathrm{MONO}=$ monocyte, GRAN = granulocyte, RBC=red blood cells, HCT = hematocrite $\mathrm{MGV}=$ mean globular volume, $\mathrm{HGB}=$ hemoglobine $\mathrm{MHC}=$ mean hemoglobin concentration, PLT = platelet.

\section{Discussion}

Feed intake was comparable among the different treatments. Tene et al. [12] came to the same conclusion, incorporating ginger powder into the ration of 
post-weaned guinea pigs. The highest value (21.13 g DM/animal/d) recorded with the Da0.5 ration is close to that of the work of Faihum et al. [13] (29.59 $\mathrm{g}$ $\mathrm{DM} / \mathrm{animal} / \mathrm{d}$ ) in guinea pigs fed with leaves of Moringa oleifera and Commelina benghalensis and that of Tsafack [14] (30.94 g DM.animal/d) in guinea pigs fed with a ration containing $1 \%$ garlic and coupled with Stylosanthes guanensis. On the other hand, this value is lower than that reported by Zambou [5] (38.12 g $\mathrm{DM} /$ animal/d) in guinea pigs subjected to a ration containing $0.5 \%$ garlic powder. Thus, the same trend is observed with the work of Mweugang et al. [15] which revealed that feed consumption varies with the level and nature of the plant material incorporated in the ration.

The highest live weight recorded at the $11^{\text {th }}$ week was obtained with the $\mathrm{Da} 0.25$ ration $(372.43 \mathrm{~g}$ ). This result is superior to that of Tsafack [14] (301 g) recorded in guinea pigs fed a ration containing $1 \%$ garlic and coupled with Stylosanthes guanensis, Miégoué et al. [1] (324.5 g) who used a ration supplemented with Arachis glabrata and Zougou et al. [4] (221 g) who fed the animals a ration with an energy content of $2800 \mathrm{Kcal} / \mathrm{kg}$ and crude protein of $18 \%$. On the other hand, Zambou [5] obtained $395 \mathrm{~g}$ with a ration containing $0.1 \%$ garlic powder. These differences are thought to be due to the chemical composition of the feed containing Dracaena arborea roots powder and to the nature of the plant material incorporated in each of these rations.

The highest mean daily weight gain was recorded in animals receiving the $\mathrm{Da} 0.25$ ration $(3.04 \mathrm{~g} / \mathrm{d})$. This result is superior to those obtained by, Zambou [5] $(2.7 \mathrm{~g} / \mathrm{d})$ in animals fed a ration containing $0.5 \%$ garlic and by Tsafack [14] $(2.74 \mathrm{~g} / \mathrm{d})$ in guinea pigs fed a ration containing $1 \%$ garlic and coupled with Stylosanthes guanensis. These differences could be explained by the presence in the ration of saponins and terpenoids from the powder of the roots of Dracaena arborea which would have stimulated the intestinal microflora, thus increasing the absorption of nutrients.

The consumption index was comparable between the different treatments. The highest value was recorded with the $\mathrm{Da} 0$ ration (7.54) and the lowest with the $\mathrm{Da} 0.25$ (6.80) ration. These values remain higher than those of Zougou et al [4] and Miégoué et al. [2] who obtained 5.20 and 4.18, respectively in animals given a ration containing $18 \%$ crude protein and in animals fed Pennisetum purpureum.

The highest live weight at slaughter (372.43 g) was recorded with the Da0.25 ration. This result is lower than that of Zambou [5] (395 g) in guinea pigs fed a ration containing $0.1 \%$ thyme. This difference is explained by the chemical composition and the level of incorporation of the additive used. On the other hand, this result is superior to that of Noumbissi [16] (253.80 g) in guinea pigs fed with a ration supplemented with Tithonia. diversifolia. In addition to the above, Zougou et al. [4] recorded $221 \mathrm{~g}$ in guinea pigs fed a ration containing $16 \%$ protein. These differences could be explained by the nature of the bioactive molecules contained in the powder of the roots of Dracaena arborea, which could have favored the growth of guinea pigs. 
The highest commercial and conventional carcass weights (161.75 $\mathrm{g}$ and 307.75 g respectively) were recorded with the Da0.25 ration. These results are superior to those obtained by Zambou [5] (114.83 g and $252.50 \mathrm{~g}$ ) respectively for the weights of commercial and conventional carcasses in guinea pigs fed a ration containing $0.5 \%$ garlic. These differences could be related to the weight of the animals at slaughter, the chemical composition and the level of incorporation of the additive in the ration.

The highest commercial and conventional carcass yields $(39.5 \%$ and $75.75 \%$ respectively) were recorded with the D0.25 ration. The highest conventional carcass yield is comparable to that of Zambou [5] (70.67\%) in guinea pigs fed a ration containing $1 \%$ thyme. These results may be linked to the chemical composition of the powder of Dracaena arborea roots contained in the ration.

The highest liver weight ( $11.33 \mathrm{~g}$ ) was obtained with the $\mathrm{Da} 0.75 \%$ ration. This result is superior to that obtained by Zougou et al. [4] (10.96 g) and Zambou [5] $(9.68 \mathrm{~g})$ respectively in guinea pigs fed a ration containing $18 \%$ protein and in those fed a ration containing $1 \%$ garlic. From the above, Noumbissi [16] obtained $9.20 \mathrm{~g}$ in guinea pigs fed with a ration supplemented with $T$. diversifolia. The result obtained in the present work could be linked to the presence of the anti-nutritional factors contained in the powder of Dracaena arborea roots, which would have stimulated the liver to intervene in the detoxification process of the rations.

The highest small intestine density $(0.08 \mathrm{~g} / \mathrm{cm})$ was obtained with the Da0 ration and the lowest $(0.06 \mathrm{~g} / \mathrm{cm})$ was obtained with the $\mathrm{D} 0.25 \%$ ration. These results are close to those obtained by Zougou et al. [4] $(0.09 \mathrm{~g} / \mathrm{cm}$ and $0.08 \mathrm{~g} / \mathrm{cm})$ in guinea pigs fed a ration containing $16 \%$ protein. Similarly, Zambou [5] obtained $0.07 \mathrm{~g} / \mathrm{cm}$ and $0.08 \mathrm{~g} / \mathrm{cm}$ in guinea pigs fed a ration containing $0.5 \%$ and $1 \%$ garlic. However, these different values are linked to the length and weight of the intestine. Indeed, the larger the intestine, the greater the microbial population and the greater the absorption of nutrients [17]. Moreover, these results are much lower than the $0.18 \mathrm{~g} / \mathrm{cm}$ obtained by Tendonkeng et al. [18] in guinea pigs fed with Pennisetum purpureum and supplemented with Desmodium intortum. This can be explained by the high level of crude protein contained in this legume which improves digestibility and therefore absorption of nutrients, hence the development of the absorption surface.

The highest values for granulocytes $\left(0.250 .10^{3} / \mu \mathrm{l}\right)$, platelets $\left(805.10^{3} / \mu \mathrm{l}\right)$ and for lymphocytes $\left(6.92 .10^{3} / \mu \mathrm{l}\right)$ were, respectively, obtained with the rations $\mathrm{Da} 0$, $\mathrm{Da} 0.5$ and Da0.75. These values corroborate the observations of Djoumessi et al. [19] who found that the incorporation of Cucuma longa powder as a food additive in the ration of guinea pigs significantly improved these blood parameters. The explanation given by them was that phytobiotics are often used to purify blood and increase immunity by stimulating the body's defense cells. In addition, Zambou [5] obtained $395.10^{3} / \mu \mathrm{l}$ for platelets, $5.56 .10^{3} / \mu \mathrm{l}$ for lymphocytes and $4.35 .10^{3} / \mu \mathrm{l}$ for granulocytes. These different values might be linked to the chemical composition and the level of incorporation of the additive used. Over- 
all, these values fall within the range of reference values of guinea pig hematological parameters governed by Quesenberry et al. [20].

\section{Conclusion}

At the end of this work it appears that the incorporation of powder from the roots of Dracaena arborea at $0.25 \%$ in the ration of weaned guinea pigs made it possible to obtain the highest live weight and weight gain at the $11^{\text {th }}$ week of age. The Da0.25 and Da0.5 rations produced the highest carcass yields (commercial and conventional) and the highest caecum weight. Powder from the roots of Dracaena arborea had a significant effect on granulocytes, platelets and lymphocytes. But overall, the results were within the range of normal guinea pig haematological parameters. In short, the powder from the roots of Dracaena arborea is an appreciable source of protein that can be used up to $0.25 \%$ in the food, to improve the growth of guinea pigs, without abnormalities on their digestive organs and their haematological parameters.

\section{Conflicts of Interest}

The authors declare that there is no conflict of interest between them.

\section{References}

[1] Miégoué, E., Tendonkeng, F., Mweugang, N.N., Lemoufouet, J., Fossi, J., Ntsafack, P. and Pamo, E.T. (2018) Effect of Arachis glabrata Levels in the Diet on Reproduction and Pre-Weaning Growth Performance of Guinea Pigs (Cavia porcellus L) Fed on Panicum maximum. International Journal of Animal Science and Technology, 2, 36-44.

[2] Miegoue, E., Tendonkeng, F., Lemoufouet, J., Noumbissi, M.N.B., Mweugang, N.N., Zougou, T.G., Nkouadjio, M.F., Boukila, B. and Pamo, T.E. (2016) Croissance pré-sevrage des Cobayes nourris au Panicum maximum supplémenté avec une ration contenant Arachis glabrata, Calliandra calothyrsus ou Desmodium intortum comme source de protéines chez le cobaye. International Journal of Biological and Chemical Sciences, 10, 313-325. https://doi.org/10.4314/ijbcs.v10i1.24

[3] Herman, Y.C., Fon, D.E., Meutchieye, F., Niba, A.T., Manjeli, Y. and Djikeng, A. (2014) Cavies for Income Generation, Manure for the Farm and Meat for the Table. Scholarly Journal of Agricultural Science, 4, 260-264.

[4] Zougou, T.G., Tendonkeng, F., Miégoué, E., Noumbissi, M.N.B., Mboko, V.A., Matimuini, F.N., Boukila, B. and Pamo, E.T. (2017) Performances de production des cobayes (Cavia porcellus L.) en fonction du niveau de protéines alimentaires. International Journal of Biological and Chemical Sciences, 11, 828-840. https://doi.org/10.4314/ijbcs.v11i2.24

[5] Zambou, D.K. (2019) Effets de la poudre d'ail et de thym comme additifs alimentaires sur les performances zootechniques du Cochon d'Inde (Cavia porcellus). Mémoire de Master of Science en Biotechnologie et Productions Animales, Université de Dschang-Cameroun, Dschang, Cameroun.

[6] Brenes, A. and Roura, E. (2010) Essential Oils in Poultry Nutrition: Main Effects and Modes of Action. Animal Feed Science Technology, 158, 1-14.

https://doi.org/10.1016/j.anifeedsci.2010.03.007 
[7] Ker-Gawl (2019) Biodiversity Education and Research Greenhouses. Ecology and Evolutionary Biology, University of Connecticut, Mansfield. https://florawww.eeb.uconn.edu

[8] Ong, M.G., Yusuf, S.N.A.M. and Lim, V. (2016) Pharmacognostic and Antioxydant Properties of Dracaena sanderiana Leaves. Multidisciplinary Digital Publishing Institute, 5, Article No. 28. https://doi.org/10.3390/antiox5030028

[9] Abdel-Ghaney, D., El-Far, A., Sadek, K.M., El-Sayed, Y.S. and Abdel-Latif, M.A. (2017) Impact of Dietary Thyme (Thymus vulgaris) on Broiler Chickens Concerning Immunity, Antioxidant Status, and Performance. Alexandria Journal of Veterinary Sciences, 55, 169-179. https://doi.org/10.5455/ajvs.275352

[10] Chakraborty, S.B. and Hancz, C. (2011) Application of Phytochemicals as Immune Stimulant, Antipathogenic and Antistress Agents in Finfish Culture. Reviews in Aquaculture, 3, 103-119. https://doi.org/10.1111/j.1753-5131.2011.01048.x

[11] Steele, R.G. and Torrie, J.H. (1980) Principles and Procedures of Statistics. McGraw Hill Book C, New York, 633 p.

[12] Téné, M.A.L., Miégoué, E., Noumbissi, M.N.B., Ntsafack, P., Sawa, C., Nguedia, G., Matumuini, N.F.E., Zougoug. T. and Tendonkeng, F. (2020) Croissance post-sevrage des cobayes (Cavia porcellus) en fonction du niveau de la poudre de gingembre (Zingiber officinale) comme additif alimentaire. International Journal of Biological and Chemical Sciences, 14, 3341-3352. https://doi.org/10.4314/ijbcs.v14i9.29

[13] Faihun, A.M.L., Zoffoun, A.G., Hounzangbe-Adote, M.S., Samati, G., Akouedegni, C.G., Akakpo, G.A., Wabi, F., Kulo, A. and Houndonougbo, F. (2019) Effet des feuilles de Moringa oleifera et de Commelina benghalensis sur les performances de croissance et les caractéristiques de carcasse des cochons d'inde (Cavia porcellus) au Sud-Bénin. Journal of Applied Biosciences, 134, 13657-13671. https://doi.org/10.4314/jab.v134i1.4

[14] Tsafack, U. (2019) Effets de la poudre d'ail comme additif alimentaire couplée au Stylosanthes guanensis sur les performances Zootechniques du Cochon d'Inde ( $\mathrm{Ca}$ via porcellus). Mémoire de Master of Science en Biotechnologie et Productions Animales, Université de Dschang-Cameroun, Dschang.

[15] Mweugang, N.N., Tendonkeng, F., Matumuini, F.N.E., Miégoué, E., Boukila, B. and Pamo, E.T. (2014) Influence of the Inclusion of Gradel Levels of Cassava Leaf Meal in the Diet on Post-Partum Weight and Pre-Weaning Growth of Guinea Pigs (Cavia porcellus L.). International Journal of Agriculture Innovations and Research, 2, 939-945.

[16] Noumbissi, M.N.B. (2016) Evaluation des performances de production des cobayes (Cavia porcellus L.) soumis à différents niveaux de supplémentation avec Tithonia diversifolia. Thèse de Doctorat $(\mathrm{PhD})$ en Biotechnologie et Productions Animales, Université de Dschang-Cameroun, Dschang.

[17] Boussarie, D. (2000) Le Cobaye, milieu de vie et Alimentation. Le nouveau praticien vétérinaire, 2, 65-67.

[18] Tendonkeng, F., Nkana, K.J.G., Mweugang, N.N., Germanus, S.B., Semi, A.Y., Awantu, C., Ntsafack, P., Wangba, T.C., Noumbissi, M.N.B., Matho, A. and Miégoué, E. (2020) Growth Performances and Carcass Characteristics of Guinea Pigs Feed on Pennisetum purpureum Supplemented with Legumes as Sources of Protein. Livestock Research International, 8, 48-55.

[19] Djoumessi, T.F.G., Tendonkeng, F., Miégoué, E., Noumbissi, B.M.N., Fokom W.D., Mube, K.H. and Ebile, A.D. (2020) Effect of Dietary Incorporation of Curcuma 
Longa Powder on Haematology and Serological Properties of Guinea Pigs (Cavia porcellus). Open Journal of Animal Sciences, 10, 750-760.

https://doi.org/10.4236/ojas.2020.104049

[20] Quesenberry, K.E., Donnelly, T. and Mans, C. (2012) Chapter 22: Biology, Husbandy and Clinical Technics of Guinea Pigs and Chinchillas. In: Quesenberry, K.E. and Carpenter, J.W., Eds., Ferrets, Rabbits and Rodents: Clinical Medicine and Sugaring, 3rd Edition, Saunders Elsevier, St Louis, 279-294.

https://doi.org/10.1016/B978-1-4160-6621-7.00022-1 